\title{
A note on effect of benzoic acid supplementation on the performance and microbiota population of broiler chickens
}

\author{
D. Józefiak ${ }^{1,2}$, S. Kaczmarek, M. Bochenek and A. Rutkowski \\ The August Cieszkowski Agricultural University of Poznań, \\ Department of Animal Nutrition and Feed Management \\ Wolyńska 33, 60-637 Poznań, Poland
}

(Received 8 December 2006; revised version 2 February 2007; accepted 2 May 2007)

\begin{abstract}
In order to determine the efficiency of benzoic acid, a feeding experiment was carried out on 400 one-day-old Cobb 500 cockerels. The birds were divided into four dietary treatments: control without additives, or with $2.5,5$ and $7.5 \mathrm{~g}$ of benzoic acid per $\mathrm{kg}$ diet, respectively. Performance was similar in birds fed the control diet and that with $2.5 \mathrm{~g}$ benzoic acid. The dietary inclusion of 5 and 7.5 benzoic acid per $\mathrm{kg}$ depressed growth and increased the feed conversion ratio $(\mathrm{P}<0.05)$. The $\mathrm{pH}$ of the caecal contents tended to decrease following increased benzoic acid supplementation. No differences were found in the $\mathrm{pH}$ of ileal and gizzard digesta. Lactic acid bacteria populations in the caecal contents were most numerous in the group fed the diet with $7.5 \mathrm{~g}$ benzoic acid $(\mathrm{P}<0.05)$. Coliform bacteria tended to decrease in the crop and ileal contents following increased benzoic acid supplementation, while there was no effect on the caecal contents.
\end{abstract}

KEY WORDS: broiler chickens, feed supplementation, benzoic acid, intestinal microflora

\section{INTRODUCTION}

The impact of gastrointestinal microbiota on animal health and growth performance has been demonstrated in animals fed antibiotic growth promoters (AGP). Apart from many doubts concerning the usage of antibiotic growth promoters, it is also well documented that their presence in poultry diets enhances broiler growth and improves feed conversion ratio. In recent years, we have seen growing interest in feed additives that may be alternatives for AGPs. These include organic acids as well as their mixtures (Ricke, 2003). The modes of their

\footnotetext{
${ }^{1}$ Corresponding author: e-mail: damjo@au.poznan.pl

${ }^{2}$ Author is beneficent of The Foundation of Polish Science
} 
action differ, but they are all considered to be bacteriostatic agents. Benzoic acid and its salts are common food preservatives but are also used as feed additives in fur animals (Polonen et al., 2000) and pigs (Mroz et al., 2000). In the available literature there is no information about effects of benzoic acid in poultry.

The objective of the experiment was to study the influence of benzoic acid supplementation on the performance of broiler chickens as well as the $\mathrm{pH}$ of digesta and selected populations of bacteria inhabiting the gastrointestinal tract.

\section{MATERIAL AND METHODS}

The total of 400 one-day-old male broiler chickens (Cobb 500) was used in the experiment. The study design consisted of four dietary treatments, 10 replicates each. The birds were kept in floor pens on straw bedding. Chickens were offered the starter type experimental diets ad libitum between 1-14 d and grower type between 15-42 days of life (Table 1). The diets were prepared without additivescontrol (C) or with, g/kg: 2.5, 5 or 7.5 pure benzoic acid. Benzoic acid replaced the respective amount of maize in the basic diet. The diets were fed in mash form. Feed intake and body weight were registered at weekly intervals, and the body weight gain (BWG) and feed conversion ratio (FCR) were calculated.

Table 1. Composition $(\mathrm{g} / \mathrm{kg})$ and nutritional value of control diets in the starter $(0-14 \mathrm{~d}$ of life $)$ and grower (15-42 d of life) period

\begin{tabular}{|c|c|c|}
\hline \multirow{2}{*}{ Item } & \multicolumn{2}{|c|}{ Diets } \\
\hline & starter type (0-14 d) & grower type $(15-42 \mathrm{~d})$ \\
\hline \multicolumn{3}{|l|}{ Ingredients } \\
\hline maize & 277.0 & 313.5 \\
\hline wheat & 250.0 & 300.0 \\
\hline soyabean meal & 376.5 & 291.0 \\
\hline rape seed oil & 49.0 & 50.0 \\
\hline monocalcium phosphate & 14.0 & 13.0 \\
\hline limestone & 4.0 & 4.0 \\
\hline Dl-methionine $20 \%$ & 10.0 & 8.0 \\
\hline L-lysine $20 \%$ & 5.0 & 6.0 \\
\hline $\mathrm{NaHCO}_{3}$ & 1.0 & 1.0 \\
\hline $\mathrm{NaCl}$ & 3.5 & 3.5 \\
\hline mineral and vitamin premix ${ }^{1}$ & 10.0 & 10.0 \\
\hline \multicolumn{3}{|l|}{ Calculated } \\
\hline $\mathrm{ME} \mathrm{MJ/kg}$ & 12.5 & 13.0 \\
\hline crude protein & 210.0 & 190.0 \\
\hline
\end{tabular}


During two days in the sixth week of the experiment, 21 chickens from each group were sacrificed by cervical dislocation. The contents of the crop, gizzard, ileum, caeca and rectum and cloaca were collected. The ileum was defined as the small intestinal segment caudal to Meckel's diverticulum. The rectum and cloaca were defined as the segment from the ileo-caecale junction to the end of the GIT. The $\mathrm{pH}$ in the contents of all gastrointestinal segments was measured with a combined glass/reference electrode (CP-40 Elmetron, Poland). The dietary concentration of dry matter, crude protein, crude fat and mineral content in the raw materials was determined using AOAC procedure (2005). Diluted caecal digesta were suspended in pre-reduced salt medium and homogenized for $2 \mathrm{~min}$ in $\mathrm{CO}_{2}$-flushed plastic bags using a stomacher homogenizer (Interscience, France). Subsequently, serial decimal dilutions were made, avoiding aeration, using the same medium according to the technique of Miller and Wolin (1974). Samples incubated under anaerobic conditions at $37^{\circ} \mathrm{C}$ for $48 \mathrm{~h}$ on MRS agar medium (Merck 1.10660, Darmstad, Germany) were used for determination of the total number of lactic acid bacteria whereas samples incubated under aerobic conditions at $37^{\circ} \mathrm{C}$ for $24 \mathrm{~h}$ on MacConkey agar (Merck 1.05465), were used for determination of the total number of coliform bacteria.

The results were subjected to one-way analysis of variance (ANOVA) followed by Duncan's multiple-range test using the statistical computer program package SAS 9.1.3 (1996). Statistical significance was established at $\mathrm{P} \leq 0.05$.

\section{RESULTS}

The performance of birds fed the diet without supplemented benzoic acid and of birds fed the diet with $2.5 \mathrm{~g}$ benzoic acid per kg were comparable. Supplementation of 5 and $7.5 \mathrm{~g} / \mathrm{kg}$ benzoic acid, however, decreased BWG and increased FCR $(\mathrm{P}<0.05)$ (Table 2).

In comparison with other treatments, the $\mathrm{pH}$ of colon contents in group B 7.5 was statistically lower (6.65 vs 7.67). The $\mathrm{pH}$ of the caeca tended to decrease following benzoic acid supplementation, but reached statistical significance only in the case of B 2.5 group $(\mathrm{P}<0.05)$. No differences were found in $\mathrm{pH}$ of ileum and gizzard contents. The $\mathrm{pH}$ of the crop content was highest in control group $\mathrm{C}$ in comparison with groups B 2.5 and B $7.5(\mathrm{P}<0.05)$.

Irrespective of the benzoic acid supplementation, no differences were found in lactic acid bacteria populations in the crop and ileum, while more lactic acid bacteria were in the caeca of group B7.5 $(\mathrm{P}<0.05)$. Coliform bacteria tended to decrease in the crop and ileal contents following increased benzoic acid supplementation but only in group B 7.5 was the difference statistically significant in comparison with the other treatments $(\mathrm{P}<0.05)$. No differences were found in the coliform bacteria populations in the caeca of broiler chickens (Table 2). 
Table 2. Performance results of broiler chickens, $\mathrm{pH}$ values and microbiota population

\begin{tabular}{|c|c|c|c|c|c|}
\hline \multirow{2}{*}{ Item } & \multicolumn{5}{|c|}{ Dietary treatments } \\
\hline & $\mathrm{C}$ & B 2.5 & B 5 & B 7.5 & SEM \\
\hline \multicolumn{6}{|l|}{ Body weight gain, $\mathrm{kg}$} \\
\hline $0-14 d$ & $0.32^{\mathrm{a}}$ & $0.33^{\mathrm{a}}$ & $0.30^{\mathrm{b}}$ & $0.25^{\mathrm{c}}$ & 0.005 \\
\hline $15-42 d$ & $2.06^{\mathrm{a}}$ & $2.06^{\mathrm{a}}$ & $1.86^{\mathrm{b}}$ & $1.62^{\mathrm{c}}$ & 0.027 \\
\hline $0-42 d$ & $2.38^{\mathrm{a}}$ & $2.39^{\mathrm{a}}$ & $2.16^{\mathrm{b}}$ & $1.87^{\mathrm{c}}$ & 0.031 \\
\hline \multicolumn{6}{|c|}{ Feed conversion ratio, $\mathrm{kg}$ feed $/ \mathrm{kg} B W G$} \\
\hline $0-14 d$ & $1.36^{\mathrm{c}}$ & $1.39^{\mathrm{bc}}$ & $1.44^{\mathrm{ab}}$ & $1.50^{\mathrm{a}}$ & 0.012 \\
\hline $15-42 d$ & $1.8^{\mathrm{b}}$ & $1.85^{\mathrm{b}}$ & $2.00^{\mathrm{a}}$ & $1.97^{\mathrm{a}}$ & 0.018 \\
\hline $0-42 d$ & $1.74^{\mathrm{b}}$ & $1.79^{\mathrm{b}}$ & $1.92^{\mathrm{a}}$ & $1.90^{\mathrm{a}}$ & 0.016 \\
\hline \multicolumn{6}{|l|}{ Digesta $\mathrm{pH}$} \\
\hline crop & $5.56^{\mathrm{a}}$ & $5.11^{\mathrm{b}}$ & $5.27^{\mathrm{ab}}$ & $5.01^{\mathrm{b}}$ & 0.073 \\
\hline gizzard & $4.23^{\mathrm{a}}$ & $4.25^{\mathrm{a}}$ & $4.26^{\mathrm{a}}$ & $3.94^{\mathrm{a}}$ & 0.077 \\
\hline ileum & $6.33^{\mathrm{a}}$ & $6.63^{\mathrm{a}}$ & $6.37^{\mathrm{a}}$ & $6.48^{\mathrm{a}}$ & 0.055 \\
\hline caeca & $7.04^{\mathrm{a}}$ & $6.72^{\mathrm{b}}$ & $6.9^{\mathrm{ab}}$ & $6.83^{\mathrm{ab}}$ & 0.483 \\
\hline rectum and cloaca & $7.67^{\mathrm{a}}$ & $7.42^{\mathrm{a}}$ & $7.65^{\mathrm{a}}$ & $6.65^{\mathrm{b}}$ & 0.996 \\
\hline \multicolumn{6}{|c|}{ Lactic acid bacteria, $\log c f u \times g-1$ digesta } \\
\hline crop & $9.60^{\mathrm{a}}$ & $8.94^{\mathrm{a}}$ & $9.57^{\mathrm{a}}$ & $9.58^{\mathrm{a}}$ & 0.181 \\
\hline ileum & $8.10^{\mathrm{a}}$ & $8.80^{\mathrm{a}}$ & $7.47^{\mathrm{a}}$ & $8.75^{\mathrm{a}}$ & 0.297 \\
\hline caeca & $9.39^{\mathrm{b}}$ & $9.38^{\mathrm{b}}$ & $9.27^{\mathrm{b}}$ & $9.87^{\mathrm{a}}$ & 0.849 \\
\hline \multicolumn{6}{|c|}{ Coliforms, $\log c f u \times g-1$ digesta } \\
\hline crop & $6.53^{\mathrm{a}}$ & $6.38^{\mathrm{a}}$ & $5.37^{\mathrm{ab}}$ & $4.13^{\mathrm{b}}$ & 0.318 \\
\hline ileum & $5.92^{\mathrm{a}}$ & $5.22^{\mathrm{a}}$ & $5.33^{\mathrm{a}}$ & $1.50^{\mathrm{b}}$ & 0.500 \\
\hline
\end{tabular}

B - benzoic acid

a,b,c means in a row with a different letter differ significantly at $\mathrm{P} \leq 0.05$

SEM - pooled standard error

\section{DISCUSSION}

Mammals eliminate ingested benzoic acid mainly by conjugation with glycine in the liver and kidneys. The conjugation product - benzoyl glycine (i.e. hippuric acid) is excreted in urine, lowering its acidity. Thus, beside bacteriostatic features, benzoic acid is considered as ammonia reducing agent, which indirectly stimulates the growth of pigs (Mroz et al., 2000). Due to differences in basic physiology of mammalian and bird species, it is hard to expect the same results in broiler chickens.

Knarreborg et al. (2002) demonstrated in the batch culture conditions that benzoic acid and, to a lesser extent, fumaric acid exerted strong bacteriocidal properties towards lactic acid bacteria. These authors suggested $\mathrm{pH}$-dependent effects on coliform bacteria and lactic acid bacteria in stomach content, and on 
coliform bacteria in the small-intestine content. The $\mathrm{pH}$ values used in the batch culture system by Knarreborg et al. (2002) were supposed to mimic physiology of the pig and so were lower than those observed in the chicken. The results of present experiment show the antibacterial effects of benzoic acid in broiler chickens, although lower bacterial counts in gastrointestinal digesta were not reflected in better performance of the birds.

Bridges et al. (1970) reported that the metabolic pathways of supplemented benzoic acid differ among mammalian species. Polonen et al. (2000) studying the effect of benzoic acid in mink, blue fox and racoon have found species-specific differences in excreting of this compound among its effects on poultry is scarce. In broilers fed vegetable diets based on soyabean meal, glycine is limiting amino acid in the early period of life (Corzo et al., 2004). Dietary benzoic acid may thus depress glycine availability and may reduce growth rate in chickens..

\section{CONCLUSIONS}

It my be concluded that dietary supplementation of pure benzoic acid at a rate exceeding $2.5 \mathrm{~g} / \mathrm{kg}$ may have negative effects on feed conversion as well as body weight gain, by broiler chickens, even though its bacteriostatic effects are dosedependent.

\section{REFERENCES}

AOAC, 2005. Association of Official Analytical Chemists, Official Methods of Analysis. 18 Edition. Arlington, VA

Bridges J.W., French M.R., Smith R.L., Williams R.T., 1970. The fate of benzoic acid in various species. Biochem. J. 118, 47-51

Corzo A., Kidd M.T., Burnham D.J., Kerr B.J., 2004. Dietary glycine needs of broiler chicks. Poultry Sci. 83, 1382-1384

Knarreborg A., Miquel N., Granli T., Jensen B.B., 2002. Establishment and application of an in vitro methodology to study the effects of organic acids on coliform and lactic acid bacteria in the proximal part of the gastrointestinal tract of piglets. Anim. Feed Sci. Tech. 99, 131-140

Miller T.L., Wolin M.J., 1974. A serum bottle modification of Hungate technique for cultivating obligate anaerobes. Appl. Microbiol. 27, 985-987

Mroz Z., Jongbloed A.W., Partanen K.H., Vreman K., Kemme P.A., Kogut J., 2000. The effects of calcium benzoate in diets with or without organic acids on dietary buffering capacity, apparent digestibility, retention of nutrients and manure characteristics in swine. J. Anim. Sci. 78, 2622-2632

Polonen I.J., Partanen K.H., Jalava T.K., Toivonen V.F., 2000. Effect of dietary glycine and benzoate level on benzoate metabolism in mink (Mustela vison), blue fox (Alopex lagopus), and raccoon dog (Nyctereutes procyonoides). J. Anim. Sci. 78, 976-986

Ricke S.C., 2003. Perspectives on the use of organic acids and short chain fatty acids as antimicrobials. Poultry Sci. 82, 632-699

SAS, 1996. SAS ${ }^{2} /$ STAT User`s Guide: Statistics Institute Inc. Cary, NC 